\title{
The Journey of Cultural Heritage Protection as a Common Goal for Human Kind: Rosenberg to Al-Mahdi
}

Erez Roman ${ }^{*}$

DOI: https://doi.org/10.21827/5d5141dfbdcbf

\begin{abstract}
Keywords
INTERNATIONAL LAW; CULTURAL HERITAGE DESTRUCTION; ARMED CONFLICTS
\end{abstract}

\begin{abstract}
This paper intends to examine and analyse the role, if any, played by motive and intent in the legal qualification and prosecution of cultural heritage destruction. The ongoing power struggles in the Near-East and the Northern Africa regions have had devastating effects on the people living in the region as well as on cultural heritage sites. ${ }^{1}$ Nevertheless, such conflictrelated destruction of cultural heritage is not new, as exemplified by the persecution of Jews prior to the Second World War. Different legal instruments such as the 1954 Hague Convention for the Protection of Cultural Property in the Event of Armed Conflict ${ }^{2}$ and the United Nations Security Council Resolution $2347^{3}$ were adopted to protect cultural heritage barring importance for all of humankind. By comparing these instruments and assessing different cases, I will study the evolving role of these factors in the legal qualification and prosecution of cultural heritage destruction. As such acts continue to take place in countries such as Syria and Afghanistan and cause the destruction of a millennium's worth of cultural memorabilia, a better understanding of the reasons behind such occurrences is key to effective prosecution.
\end{abstract}

\section{Introduction}

"The best way to take someone down is to strike him in the cultural and religious aspect, at everything that is important to him."

Erez Roman is an LL.M. student at the Vrije Universiteit Amsterdam, the Netherlands. This article was selected as the winning article of the 2019 GroJIL Student Writing Competition for Bachelor Students.

Cultural heritage is "The physical and intangible elements associated with a group of individuals which are created and passed from generation to generation" as defined by Derek Fincham in Derek Fincham, "The Distinctiveness of Property and Heritage' (2011) 115 PennStLRev 641, 668.

UNESCO, Convention for the Protection of Cultural Property in the Event of Armed Conflict (adopted 14 May 1954, entered into force 7 August 1956) (1954 Hague Convention).

United Nations Security Council Resolution 2347 (24 March 2017) UN Doc S/RES/2347.

Prosecutor v Ahmad al-Faqi al-Mahdi (Witness Testimony) ICC- 01/12-01/15 (27 September 2016). 
The current and constant power struggles in the Near-East and the Northern Africa regions has had devastating effects on the people living in the region as well as to its common cultural heritage sites. ${ }^{5}$ Nevertheless, such conflicts in which cultural heritage has been affected by arms can be dated back to earlier times such as the persecution of Jews prior to the Second World War (WWII). The most notorious example of such persecution is illustrated by the Night of Broken Glass in which synagogues, Jewish homes and businesses were torched to the ground together with hundreds of years' worth of cultural memorabilia. In light of such horrendous outcomes, different mechanisms were established to tackle this issue and attempt to protect common heritage barring importance for all of humankind.

This paper will assess the terms cultural property and cultural heritage. Furthermore, it will look at the differences between tangible cultural property which include "monuments, buildings, cultural sites, and works of art such as painting, sculpture, or the like"6 and intangible cultural property such as, oral poetry or musical traditions, ceremonial and ritual traditions and compare them to the wider definition of cultural heritage. Additionally, two well-known cases which had a major influence on the protection of cultural heritage and showcase the development curve of such protection provided by international criminal law will be assessed. To conclude, the current stage where international criminal law stands today will be discussed and exemplified by the $\mathrm{Al}$-Mahdi case. ${ }^{7}$

\section{Main International Instruments for the Protection of Cultural Heritage}

Different measures for the protection of cultural heritage in the event of armed conflict can be dated back as far as 1863 when the Lieber code, which was published during the American civil war, was created and in which such protection is mentioned in several provisions amongst other topics. The Lieber Code was a set of instructions written by Francis Lieber for the better governing of the armed units of the United States in the field during the civil war. The Code inspired following mechanisms such as the 1899, 1907 Hague Conventions which were based on its texts to attempt at increasing the protection levels for cultural heritage. These two conventions very specifically mention that 'All seizure of, destruction or willful damage done to [...], historic monuments, works of art and science, is forbidden, and should be made the subject of legal proceedings. ${ }^{8}$ Nonetheless, one must not forget that these provisions do not operate in situations where military necessity dictates otherwise. Furthermore, incidents such as the torching down of the Leuven University Library and the bombing of the Cathedral of Rheims during the first World War proved beyond doubt the insufficiency and inefficiency of protective measures guaranteed by the existing provisions.

Cultural heritage defined by Derek Fincham (n 1).

Jiri Toman, Protection of Cultural Property in the Event of Armed Conflict (1st edn, Dartmouth Publishing

Company 1996) 40. In addition, the terms cultural property and cultural heritage will be used

interchangeably in the paper.

Prosecutor $v$ Ahmad al-Faqi al-Mahdi (n 4).

Laws and Customs of War on Land (adopted 18 October 1907, entered into force 26 January 1910) art 56. 


\section{I.I The 1954 Hague Convention and its Two Protocols from 1954 and 1999}

Consequently, the newly founded United Nations Educational, Scientific and Cultural Organization (UNESCO) in conjunction with the Dutch government decided to organise a conference for establishing new and improved ways to tackle the issue at hand. The outcome of this conference was the adoption of two sets of rules: the 1954 Convention on the Protection of Cultural Property during Armed Conflict (1954 Hague Convention) and its first protocol (1954 First Protocol) which was later updated by the 1999 Second Protocol. This was an important step towards better protection of cultural property as the convention is the first comprehensive international agreement having such protection as its main task. Additionally, the convention is to be appreciated for providing the first legal definition of cultural property which includes both moveable and immoveable property. ${ }^{9}$ On the one hand the definition is highly esteemed by many since its broadness allows for a wide variety of objects to be included and protected by it. On the other hand, some argue that perhaps the definition is too broad, as Green contends that it is '[...] so vague that is clear, some measures of dissemination to inform the military [...] will be absolutely vital [...]' ${ }^{10}$ Moreover, the 1954 Hague Convention initiated a special protection regime for certain immovables which are of '[...] very great importance'. ${ }^{11}$ Under this regime, attacking such protected immovables is prohibited and an obligation to refrain from placing such immovables under threat is placed on the parties. Nevertheless, this protection can be waived under the claims of 'unavoidable military necessity'. ${ }^{12}$ This term, which will be discussed later in this paper, is regarded by many as a controversial issue since it is left relatively undefined which renders both the basic and special protection guaranteed by the Convention to be inefficient since such necessity can be interpreted in a wide plethora of ways. Additionally, the eligibility conditions of the special protection regime are perceived by many states to be stringent and as a result these states are often discouraged from considering to register their cultural properties for the programme. As a result of these rigorous conditions, there is only an insignificant amount of five properties registered for special protection, all of which are located in developed countries. ${ }^{13}$

The abovementioned shortcomings of the 1954 Hague Convention and the armed conflicts that were abundant in the end of the 1980s and beginning of the 1990s such as the Gulf War and the breakout of Yugoslavia, urged academics and legal scholars to emphasise the need for adopting a new instrument to tackle the faults of the Convention. This view, which was shared by UNESCO and its member states, led to a report in 1992 by UNESCO's director general in which it was maintained that 'Various factors seem to indicate that the Hague Convention no longer meets current requirements [...]'. ${ }^{14}$ After different alternatives were considered, it was decided that the best option to correct the faults found in the 1954

\footnotetext{
1954 Hague Convention (n 2) art 1.

Leslie Green, Essays on the Modern Law of War (2nd edn, Brill Nijhop 1999) 235.

1954 Hague Convention (n 2) art 8.

ibid art 11(2).

These properties are the Vatican, three properties in the Netherlands, and one in Germany.

Report by the Director-General on the reinforcement of UNESCO's action for the protection of the world cultural and natural heritage (1992) UN Doc $140 \mathrm{EX} / 1$.
} 
Hague convention would be to produce another protocol and as such, the 1999 second protocol was born.

The new protocol introduced new features one of which was a new category of protection which it referred to as 'enhanced protection'. This category applied protection to certain property which is of 'the greatest importance to humanity'. In addition to a property being of such great importance, in order for the protection to apply, two additional requirements must be met, namely, the property must be recognized as of great importance and protected by national law and a declaration must be made by the controlling party that it is not and will not use the property for military purposes ${ }^{15}$ After a property has been registered in the list, it becomes immune from military use and attack. ${ }^{16}$ This immunity is rendered null and void once the property has been turned into military objective. However, even in such case, the attacking party must do its utmost to prevent damage to the property and if this is not feasible, then the Protocol obliges that the decision to carry on the attack must be taken at the "highest operational level of command'. ${ }^{17}$

Another instrument which the 1999 Second Protocol introduced is individual criminal responsibility for violations of the articles found in the 1954 Hague Convention and its two protocols. ${ }^{18}$ In addition, the Protocol also declares that such violations are to be subject to universal criminal jurisdiction, meaning that a member state in which an alleged criminal is located is under the obligation to either extradite or prosecute them. ${ }^{19}$ Furthermore, in order to oversee the application of the of the Protocol, the 1999 Second Protocol Committee which comprised of twelve state parties, was created. The Committee, elected for a four-year term, also is the body determining, cancelling or suspending enhanced protection for a certain property. ${ }^{20}$

Besides the positive traditions the 1954 Hague Convention and its two protocols introduced, they also had a birth defect which bound them to life-long hardships. This, perhaps problematic, substantive issue was the inclusion of the notion of imperative military necessity. This necessity cannot and should not be equated with military convenience or even with ordinary notions of military necessity. It is defined by Kertsch as a situation in which 'the military objective cannot be reached in any other manner'. ${ }^{21}$ Thus, when the Khmer

UNESCO, Second Protocol to the Hague Convention of 1954 for the Protection of Cultural Property in the Event of Armed Conflict (adopted 26 March 1999) (1999 Second Protocol) art 10. Invasion of Iraq and The Buddhas of Bamiyan (Cambridge University Press 2017) 33. monastery by the allied forces during WWII after they had received mistaken intelligence report confirming presence of Axis armed forces in the vicinity of the property. 1999 Second Protocol (n 15) art 15. In case an extradition agreement does not exist, articles 16 and 18 of the 1999 Second Protocol can make the required legal basis available. 1999 Second Protocol (n 15), art 16 and 18.

1999 Second Protocol (n 15) art 27.

Karl Partsch, 'Protection of Cultural Property' in Dieter Fleck (ed), The Handbook of International Humanitarian Law (Oxford University Press 1995) 377, 388. 
Rouge fortified itself in and around the Angkor Wat to decrease the chances of attack, it violated the relevant rule. ${ }^{22}$

The 1999 Second Protocol further interprets the term imperative military necessity by determining that it can only be utilised when the "cultural property has, by its function, been made into a military objective and there is no feasible alternative available to obtain a similar military advantage to that offered by directing an act of hostility against that objective'. ${ }^{23} \mathrm{On}$ the one hand the notion of imperative military necessity is supported for its relative realistic and practical attitude which recognises and understands the reality of war. However, the term is also subjected to criticism by those who claim that it 'would weaken the rules obligating parties to refrain from military actions that might expose cultural property to damage or destruction' ${ }^{24}$ In addition, the protocol's definition is criticised since it is only applicable to those who signed and ratified it. This means that states which only ratified the 1954 Hague Convention and its first Protocol enjoy a wider margin of interpretation than the states which ratified both the convention and the two protocols.

\section{I.II UN Security Council Resolution 2347 for the Protection of Heritage}

UN Security Council (UNSC) Resolution 2347 is widely considered to be a 'game changer' for the international community in its attempt at protecting cultural heritage..$^{25}$ To understand this, one must first assess article 25 of the UN Charter which states that 'The Members of the United Nations agree to accept and carry out the decisions of the Security Council [... $]^{2}{ }^{26}$ Ratner explains this by saying that decisions taken by the UNSC do not need any further grounding in international law to be binding as they are by nature binding. ${ }^{27}$ Therefore, this resolution which aims to enhance the recognition and awareness of endangered cultural heritage and which followed numerous resolutions made by the UNSC can be considered binding on all UN member states. In these past resolutions, cultural heritage was a secondary consideration at best as can be seen by the different resolutions following certain occasions like the wars in Afghanistan (1990s), the invasion of Iraq (2000s) and the ongoing conflicts in Mali and Syria (2010s). ${ }^{28}$ However, dedicating an entire resolution for the protection of cultural heritage, as the Council did with Resolution 2347, signals and reaffirms that the

According to Sandesh Sivakumran, the Cambodian civil war during the period in question was most likely international armed conflict.

1999 Second Protocol (n 15) art 6(a).

Wayne Sandholtz, Prohibiting Plunder-How Norms Change (Oxford University Press 2007) 182.

UNSC Res 2347 (n 3).

Charter of the United Nations and Statute of the International Court of Justice (adopted 26 June 1945, entered into force 24 October 1945) 01 UNTS XVI, art 25.

Steven Ratner, 'The Security Council and International Law' in David Malone (ed), The UN Security Council-From the Cold War to the $21^{\text {st }}$ Century (Lynne Rienner Publishers 2004) 601.

UNSC Res 1267 (15 October 1999) UN Doc S/RES/1267; UNSC Res 1483 (22 May 2003) UN Doc S/RES/1483, para 7; UNSC Res 2071 (12 October 2012) UN Doc S/RES/2071; UNSC Res 2085 (20 December 2012) UN Doc S/RES/2085; UNSC Res 2100 (25 April 2013) UN Doc S/RES/2100; UNSC Res 2139 (22 February 2014) UN Doc S/RES/2139; UNSC Res 2199 (12 February 2015) UN Doc S/RES/2199. 
protection of cultural heritage plays an integral part in maintaining international peace and security.

\section{Cultural Property or Heritage: Problematic Terms}

The discussion regarding the definition of cultural heritage versus cultural property is a complex one and has yet to produce a globally exclusive definition. To begin with, certain authors interpret the term 'cultural property' to be more explicit than the term 'cultural heritage'; therefore, believe that both terms could be used to complement each other. However, others disagree and suggest that 'cultural property cannot be seen as a counterpart of the cultural heritage'. ${ }^{29}$ This separation of terms is clearly visible when glancing at the 1954 Hague Convention and the 1970 United Nations Educational, Scientific and Cultural Organization (UNESCO) Convention which use the term 'cultural property' while Council of Europe regulations, ${ }^{30}$ the 1972 World Heritage Convention, and the 2003 UNESCO Convention for the Safeguarding of the Intangible Cultural Heritage use 'cultural heritage' ${ }^{31}$ Furthermore, Alper Tașdelen explains the difference between the two terms by arguing that '[c]ultural heritage emphasizes the (...) emotional bond between certain items and their source nation, whereas cultural property stresses (...) ownership and the fact that cultural objects are material goods which can be traded (... $)^{32}$

The basic definition of cultural property is that something can be the property of a cultural group; thus, grant a set of collective rights regarding ownership, use, and in some cases, even title to the property if it is held in individual hands. The term, consequently, raises numerous questions relating to cultural groups, the nature of property and the correlation between them. Nevertheless, an attempt to decipher the meaning of 'Cultural heritage' will lead one to the definitions found in the 1954 Hague Convention and the 1970 UNESCO Convention which could suggest that the category of cultural heritage is broader than, and perhaps covers that of cultural property. ${ }^{33}$ Furthermore, Blake proposes that the strongest

Manlio Frigo, 'Cultural Property v Cultural Heritage: A “Battle of Concepts” in International Law?' (2004) 86 International Review of the Red Cross 367, 377.

See European Convention on the Protection of the Archaeological Heritage (adopted 6 May 1969, entered into force 20 November 1970) ETS No 066; See also Convention for the Protection of the Architectural Heritage of Europe (adopted 3 October 1985, entered into force 1 December 1987) ETS No 121.

Janet Blake, 'On Defining the Cultural Heritage' (2000) The International and Comparative Law Quarterly 61, 65; The 1978 UNESCO Recommendation gives the following definition: 'movable cultural property shall be taken to mean all movable objects which are the expression and testimony of human creation or of the evolution of nature and which are of archaeological, historical, artistic, scientific or technical value and interest." UNESCO, 'Recommendation for the Protection of Movable Cultural Property' United Nations Educational Scientific Cultural Organization (28 November 1978).

Alper Tașdelen, The Return of Cultural Artefacts: Hard and Soft Law Approaches (Springer International Publishing 2016) 4.

Manlio Frigo (n 29) 369; The 1954 Hague Convention (n 2) art 1 defines cultural property as "movable or immovable property of great importance to the $\mathrm{CH}$ of every people; UN Educational, Scientific and United Nations Educational Scientific and Cultural Organization Convention for the Protection of Cultural Property in the Event of Armed Conflict (14 May 1954) art 1; UNESCO, Convention on the Means of Prohibiting and Preventing the Illicit Import, Export and Transfer of Ownership of Cultural Property (adopted on 14 November 1970, entered into force 24 April 1972) (1970 UNESCO Convention) art 2. The 1970 UNESCO convention states in article two that 'the illicit import, export and transfer of ownership of 
argument against the use of the term 'cultural property' is that it is too limited in scope to encompass the possible range of both tangible and intangible cultural property. ${ }^{34}$ Moreover, Blake states that the 'tangible' element relates only to physical remains which tend to naturally fall under law protecting cultural heritage, while 'intangible' usually relates to knowledge or ideas and clearly portrays the limitations of applying the term cultural property to such elements. Additionally, Prott criticizes 'cultural property' and suggests 'that it is a purely Western legal category which is far too narrow' and that it should be disbanded to allow for the broader term of cultural heritage to take place..$^{35}$

To conclude this section, it is well established that the term cultural heritage is widely recognized and globally used by many non-legal professions in both the past and the present who are highly unlikely to use the term cultural property unless in a legal context. However, even the law which encompasses the notion of cultural property is losing its' importance as legal scholars increasingly recognize that it is inadequate for the vast range of matter covered by 'cultural heritage'. ${ }^{36}$

\section{Protection of Cultural Heritage: Progress Curve}

Historically not much consideration was given to the protection of cultural heritage sites in times of an armed conflict. The reigning motto was that the aim legitimizes the acts and therefore religious, ethnical, and cultural memorabilia were destroyed to allow for the aim to be realized. However, through different historical advancements this motto has suffered a considerable amount of damage and recently this damage has intensified with more and more international organizations such as UNESCO along with the United Nations itself condemning such actions. ${ }^{37}$

cultural property is one of the main causes of the impoverishment of the cultural heritage of the countries of origin of such property'.

"Tangible cultural property might include monuments and complexes of buildings, sites of archaeological or historic significance, ancient works of art (including rock carvings and cave paintings), ethnographic items, places associated with the development of a technology or industry, landscapes and topographical features, grave sites, sacred places and ritual sites, natural features endowed with special cultural significance to a people, items of clothing or jewelry, weapons, daily utensils, ritual items, musical instruments, objects associated with certain historical characters, coins, carved obsidian or ivory, fossils, skeletal remains, pollen samples, ancient copper or tin mines. Intangible cultural property might include the know-how related to a particular type of ship-building, oral poetry or musical traditions, ceremonial and ritual traditions, aspects of the way of life of certain societies and the special relationship between certain peoples and the land they inhabit." Janet Blake (n 31) 66. In addition, according to UNESCO, cultural heritage is the legacy of physical artefacts and intangible attributes of a group or society that are inherited from past generations, maintained in the present and bestowed for the benefit of future generations. UNESCO, 'Tangible Cultural Heritage' (UNESCO Office in Cairo) <http://www.unesco.org/new/en/cairo/culture/tangible-cultural-heritage/> accessed 29 June 2019. Lyndel Prott, 'International Standards for Cultural Heritage' UNESCO World Culture Report (UNESCO publishing 1998) 222-236. of Cultural Property 307, 319. 


\section{III.I Nuremberg International Military Tribunal- Alfred Rosenberg}

In addition, international law was traditionally viewed as a body of laws created for states and used to govern their relations. Nevertheless, it has developed significantly over time and is now believed to apply to individuals and places a responsibility to adhere to it at both the domestic and international level in front of tribunals and courts. Perhaps the most visible start of this process was the ratification of the 1907 Hague Regulations concerning the Laws and Customs of War on Land (1907 Hague Regulations) which, although are thought by many to fail at protecting cultural property during the First World War (WWI), ${ }^{38}$ were used as customary international law by the Nuremburg International Military Tribunal (Nuremberg Tribunal) to prosecute German major war criminals for their war-crimes in WWII. ${ }^{39}$

Many scholars contend that the Nuremberg Tribunal had a sole purpose of prosecuting German high-ranking officials only in relation to the mass atrocities Germany committed against civilian populations under their supervision. The abovementioned is perhaps true, however, in some of the Nuremberg cases the contrary is upheld. The Nuremberg trials set a precedent for crimes committed against cultural heritage and established individual criminal responsibility for such crimes. A closer assessment of article six of the Charter of the International Military Tribunal (IMT Charter), which the court used in its judgements, reveals that war crimes possess a wide definition which includes 'plunder of public or private property' as well as the 'wanton destruction of cities, towns or villages' not justified by military necessity. ${ }^{40}$

One of the German high-ranking officials to be prosecuted was Alfred Rosenberg, who was one of the most influential Nazi ideologists. During his career, Rosenberg held many highly authoritative posts. One of these roles was the head of the Einsatzstab Rosenberg unit which '... became a synonym for the worst plundering of art works in the modern history'. ${ }^{41}$ Rosenberg's case depicts the aforementioned in an excellent way since, as an expression of individual criminal responsibility, he was tried and found guilty of several war crimes. This includes the part he played in organizing and directing the infamous Einsatzstab Rosenberg which plundered museums and confiscated different artifacts amongst other crimes. ${ }^{42}$

The Versailles Treaty, which marked the end of WWI, established extensive reparations caused by the Germans. Several looted artefacts were forcefully returned to their original owners, for example, 'The Germans were ordered to return the original Koran of the Caliph Othman, which was removed from Medina by the Turkish authorities, and the skull of the Sultan Mkwawa, which was removed from the Protectorate of German East Africa, to the King of the Hedjaz.' Peace Treaty of Versailles (Versailles 28 June 1919) article 246. However, it must be remembered that although reparations were ordered, '...no German was ever prosecuted for damage to cultural property during World War I ...', David Keane, 'The Failure to Protect Cultural Property in Wartime' (2004) 14 DePaul Journal of Art, Technology \& Intellectual Property Law 1, 8. 30 NYUJIntIL\&Pol 201, 210. Tribunal (Nuremberg 1947) 295 <https://www.loc.gov/rr/frd/Military_Law/pdf/NT_Vol-I.pdf> accessed 29 June 2019. 
Regardless of his conviction, several scholars are raising question of doubt regarding the integrity of those who adjudicated the case. Birov writes that '...countries presiding over proceedings, [for example] the former Soviet Union, participated in their own cultural pillage (...) in retaliation for Hitler's destruction of cultural heritage in Russia' ${ }^{43}$

Regardless of the controversies surrounding it, the outcome of Rosenberg's trial stands as an important precedent according to which individuals may be held criminally liable for the pillage and destruction of cultural heritage. Birov adds that '...this precedent is enormously influential in advancing international law in this area' ${ }^{44}$

\section{III.II International Criminal Tribunal for the Former Yugoslavia- Pavle Strugar and Duško Tadić}

On 6 December 1991, the old city of Dubrovnik was heavily bombarded as part of the hostilities happening at that time in the Balkan states. One of the men responsible for this military campaign was Pavle Strugar, the commander of the Second Operational Group of the Yugoslav People's Army (JNA) whom were operating in the wider Dubrovnik area. As part of their operations in the area, the group took part in the unlawful and highly criticized shelling of Dubrovnik's old city. This tragic occurrence turned out to be of great significance since it led to a further development of cultural property protection under international law. In the aftermath of the hostilities in the former Yugoslavia, the International Criminal Tribunal for the Former Yugoslavia (ICTY) was created by a UN Security Council Resolution 827 with the main purpose of prosecuting international humanitarian law violations during the hostilities. ${ }^{45}$

One of the cases brought before the tribunal was on Pavle Strugar, who was tried for his responsibility and role in the bombardment of Dubrovnik's old city and found guilty of the war crime of 'destruction or willful damage done to institutions dedicated to religion, charity and education, the arts and sciences, historic monuments and works of art and science'. ${ }^{46}$ The ICTY chamber found him guilty in two instances and chose to portray the importance of cultural heritage protection by noting that cultural heritage destruction is a war crime irrespective of whether it was an international or non-international conflict since the jurisprudence of the International Tribunal indicates that protection of cultural property in customary international law applies in all situations of armed conflict'. ${ }^{47}$ Furthermore, the ICTY stated at the occasion of the conviction of those responsible for the shelling of

Victoria Birov (n 41) 211; In addition, 'Estimates reveal that 1,000,000 books, 175,000 coins and medals, and 55,000 paintings, sculptures, and artworks taken from Germany are being exhibited in Russian state museums.' 'Russia Keeps WWII-Looted' (1998) Newsday.

UNSC Res 827 (25 May 1993) UN Doc S/RES/827.

Updated Statute of the International Criminal Tribunal for the former Yugoslavia (adopted 25 May 1993, published September 2009) art 3(d)

<http://www.icty.org/x/file/Legal\%20Library/Statute/statute_sept09_en.pdf> accessed 29 June 2019. 
Dubrovnik, that 'the destruction of assets listed on the World Heritage List constituted a factor of aggravated individual responsibility'. ${ }^{48}$

In addition to the Strugar case, the ICTY also gave a very important ruling in the highly influential Prosecutor v. Tadic (Tadic). Duško Tadic, a Bosnian Serb, was born in Kozarac, Bosnia and Herzegovina in 1955. He became a leading member of the Serbian Democratic Party (SDS) which is still considered by many to be an extremely nationalistic party which strives for the creation of Greater Serbia and is known for its xenophobic ideologies. ${ }^{49}$ As a leading member of the SDS and different paramilitary groups, Tadic was charged with multiple offences including war crimes. However, for the purpose of this paper, the importance of this case stems from it being the ICTY's declaration that the intentional destruction of cultural heritage is criminalized under customary international law which cemented protection of cultural heritage as binding upon all states. ${ }^{50}$

In conclusion of both cases mentioned above, a significant amount of progress was made by the ICTY in protecting cultural heritage during armed conflict. The Tribunal crystalized destruction of cultural or religious heritage as a war crime and through its elaborate case law shed light on future prosecution of such crimes. ${ }^{51}$

\section{Protection of Cultural Heritage: Current Stage IV.I International Criminal Court (ICC): Ahmad Al Faqi Al Mahdi (Al Mahdi)}

Another significant sign of progress is the initiation of investigations into the situation in Mali and the subsequent production of an arrest warrant against Ahmad Al Faqi Al Mahdi (A1 Mahdi), one of the religious leading members of the Salafi-jihadist group called Ansar AlDin. This group is regarded to be accountable for the vast majority of crimes against cultural heritage committed during the internal armed conflict in Mali between 2012 and 2013. ${ }^{52}$

Al-Mahdi, also known as Abou Tourab, was born in a city called Agoune which is approximately 100 kilometers from the historic town of Timbuktu. He served as the head of the 'Hisbah' also referred to as the Islamic religious police in Timbuktu and was one of the four Ansar Al-Din top commanders in the city during its vicious occupation of the city in 2012. On 26 September 2015, Al-Mahdi was extradited from Niger, to which he had escaped from Mali, to the custody of the ICC, who indicted him on numerous charges of war-crimes, specifically those found under Article 8(2)(e)(iv) of the Rome Statute which states that war

Elisa Novic, The Concept of Cultural Genocide: An International Law Perspective (OUP 2016) 129.

Greater/ Great Serbia is a term used by Serbian Nationalists to describe a Serbian state which would incorporate all traditionally important regions, including some which are outside of Serbia but are populated by Serbs; In addition, the US government is still investigating and sanctioning the SDS as can be seen in US Department of the Treasury, 'Recent OFAC Actions' (US Treasury, 2004)

<https://www.treasury.gov/resource-center/sanctions/OFAC-Enforcement/pages/20041216.aspx> accessed 29 June 2019.

Tadic Case (Decision) ICTY-94-1 (2 October 1995), para 98.

Andrzej Jakubowski, 'State Responsibility and the International Protection of Cultural Heritage in Armed Conflicts' (2015) 1 Santander Art and Culture Law Review 147, 154.

Mapping Militant Organizations, 'Ansar Dine' (Stanford University, 2009)

<http://stanford.edu/group/mappingmilitants/cgi-bin/groups/print_view/437> accessed 29 June 2019. 
crimes include 'intentionally directing attacks against buildings dedicated to religion, education, art, science or charitable purposes, historic monuments, hospitals and places where the sick and wounded are collected, provided they are not military objectives'. ${ }^{53}$

Scholars hailed the ICC for its handling of the Al-Mahdi case and called it a big victory for the ICC and international criminal law. To the surprise of many, the case unfolded relatively quickly and in an efficient manner. From the official Malian referral of the case to the ICC until the end of the Al Mahdi trial with the granting of the judgement only four years had passed, a record time for the notoriously slow court. ${ }^{54}$ Although some have applauded the quick and efficient prosecution of Al-Mahdi, others criticized the court's choice of adjudicating the relatively unknown Al-Mahdi for a rather insignificant crime..$^{55}$

The conviction was a noteworthy legal development in international criminal law for several reasons. Firstly, it showcased the ICC prosecutor's interest in adjudicating cases in which cultural heritage sites are deliberately targeted and wrecked during armed conflicts. Furthermore, such adjudication gives out signals that the ICC will not tolerate future violations of international criminal law regarding the protection of cultural heritage and will vigorously prosecute such attacks by those found guilty. ${ }^{56}$ The abovementioned is considered by many as an important development especially in such time where armed conflicts around the world cause a significant amount of damage to cultural property..$^{57}$

Secondly, Al-Mahdi was the first case brought before the ICC for prosecution which concerned the destruction of cultural heritage and it may offer insights into the different layers of substantive international criminal law in the specific area and how the ICC interprets the relevant legal provisions found in the Rome Statute in addition to other sources of law and how it uses them to define 'war crime' in the context of destruction of cultural property.

Thirdly, Al Mahdi, for the first time in the court's history, pled guilty in exchange for a betterment in his sentencing. ${ }^{58}$ Although the facts of Al-Mahdi are quite unique, it is interesting to examine the effects that admission of guilt, expression of remorse and proper

Rome Statute of the International Criminal Court (adopted 17 July 1998, entered into force 1 July 2002) 2187 UNTS 90, art 8(2)(e)(iv).

Mark Kersten, 'Some Thoughts on the al Mahdi Trial and Guilty Plea' (2016) Justice in Conflict $<$ https://justiceinconflict.org/2016/08/24/some-thoughts-on-the-al-mahdi-trial-and-guilty-plea> accessed 29 June 2019.

Amnesty International's Senior Legal Advisor Erica Bussey said that '...we must not lose sight of the need to ensure accountability for other crimes under international law, including murder, rape and torture of civilians...'; Amnesty International, 'Mali: ICC trial over destruction of cultural property in Timbuktu shows need for broader accountability' (2016) Amnesty International <https://www.amnesty.org/en/latest/news/2016/08/mali-icc-trial-over-destruction-of-cultural-propertyin-timbuktu-shows-need-for-broader-accountability/> accessed 29 June 2019.

Marina Aksenova, 'The Al Mahdi Judgment and Sentence at the ICC: A Source of Cautious Optimism for International Criminal Justice (2016) EJIL < https://www.ejiltalk.org/the-al-mahdi-judgment-andsentence-at-the-icc-a-source-of-cautious-optimism-for-international-criminal-justice/> accessed 29 June 2019.

Marina Lostal, 'Prosecutor v Al Mahdi: A Positive New Direction for the ICC?' (2016) OpinioJuris <http://opiniojuris.org/2016/10/26/prosecutor-v-al-mahdi-a-positive-new-direction-for-the-icc/> accessed on 29 June 2019.

Mark Kersten (n 54). 
cooperation with the investigative process had on the court's judgement. The Al-Mahdi case might be used as a guide for future cases, considering the different methods of action used by the ICC when it deals with plea agreements and might shed some light on sentencing of defendants who admit their guilt to the court.

Al-Mahdi is a great example of a growing idea according to which the destruction of cultural heritage should be equated to an attack on the values of humanity as a whole. Moreover, since law is closely connected to the general norms of society, the increasing recognition of international law that the destruction of cultural heritage is an international crime can and should continue. Regardless of the few cases ending up in courts, it is supremely important for the protection cultural heritage, that international criminal law regard such attacks in a serious manner which should lead to severe consequences. ${ }^{59}$

\section{Conclusion}

Recent armed conflicts such as those in Syria, Iraq, Afghanistan and Mali feature multiple issues which the international community must stand up to and act against when attempting to protect cultural heritage armed conflicts. These challenges and the severity of the threat stemming from them, oblige the international community to reach an agreement regarding whether to use the term cultural property or cultural heritage and how state should act to protect it.

This paper showcased the extensive debate regarding the different terms and discussed the progress of cultural protection by the international community using international law. Regardless of the optimistic message this paper wishes to convey, perhaps international law cannot invest more effort into protecting cultural property in times of armed conflict because frequently, the majority of that effort is used to protect life. This is the reality of war, and despite the increasing protection provided by international law, war is always accompanied by uncertainty. Keane adds that '[i]f war cannot be prevented, it may seem that the destruction of cultural property cannot be prevented ${ }^{\prime}{ }^{60}$ Nonetheless, it is a prevailing hope that as the protection of cultural heritage increases in capacity and international law '...erodes the impunity of wartime...' that the perceived legitimacy of the regime governing cultural heritage will gain a wider margin of acceptance. 